\title{
The Artistry and Creative Process in the Making of Malang Masks in East Java Kesenian dan Proses Kreatif dalam Penciptaan Topeng Malang di Jawa Timur
}

Guntur

Batik Department, Craft Department, Faculty of Fine Art and Design, Indonesian Institute of the Arts Surakarta

guntur@isi-ska.ac.id

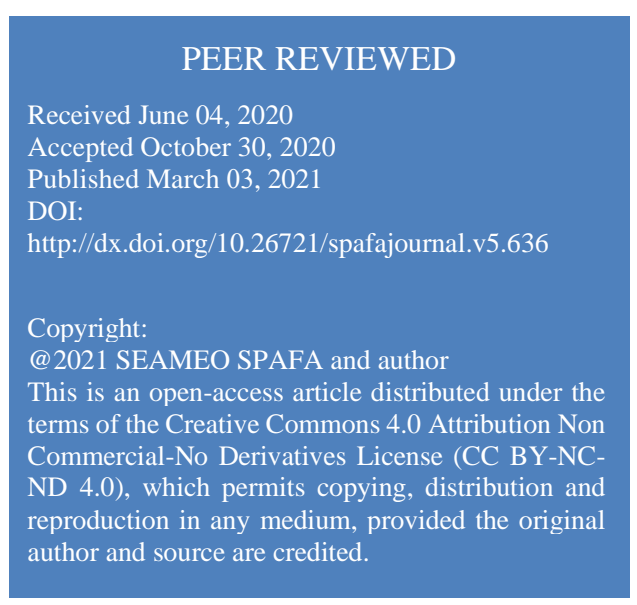

\begin{abstract}
The creative process in Malang mask making has a strong tradition of creation which has produced a unique form. The Malang mask art has been popularized based on the Panji story. Despite being properties of an art performance, the masks are works of art. The visual characteristics of the faces and their carved ornaments are the main elements that determine the typology of the mask's facial appearance. The characteristics of form, color, expression, and function create a unique style or identity of the group of traditional mask artists in Malang. Masks can be classified according to four general types of character: the figure of Panji, antagonistic characters, servants, and animals. In terms of the traditionality of creation, including aspects of material, technique, and function in the community of craftsmen, the style of the masks refers to previously existing forms. This essay is a qualitative description of the artistry of Malang masks, through the formation of the Panji story based on kidung as indigenous stories in the practice of adaptive Hinduism - and leaning on a dichotomy with the Kakawin form. Malang masks are used by the wayang topeng community in art performances to present the narration of the Panji story - against the spiritual cultural background of the common people.
\end{abstract}

Process kreatif dalam pembuatan topeng Malang memiliki tradisi penciptaan yang kuat, dan telah menghasilkan bentuk yang khas. Topeng Malang dipopulerkan berdasarkan kisah Panji. Meskipun menjadi properti seni pertunjukan, topeng adalah karya seni. Karakteristik visual wajah dan ornamen ukir merupakan elemen utama yang membentuk tipologi perwajahan topeng. Karakteristik pada bentuk, warna, ekspresi, serta fungsi, menghasilkan gaya atau identitas unik dari kelompok seniman topeng tradisional di Malang. Klasifikasi topeng ada pada empat tipologi umum karakter tokoh: sosok Panji, tokoh antagonis, tokoh abdi, dan tokoh binatang. Dari sisi tradisionalitas penciptaan, yaitu aspek materialitas, teknik, dan fungsinya di komunitas perajin, gaya topeng mengacu kepada bentuk topeng yang ada sebelumnya. Esai ini mendeskripsikan secara kualitatif 
perwujudan artistik topeng Malang, melalui formasi kisah Panji - berdasarkan kidung sebagai cerita asli dalam praktek Hinduisme adaptif - dan bersandar pada dikotomi dengan bentuk Kakawin. Topeng Malang digunakan oleh masyarakat topeng wayang dalam pertunjukan seni untuk menampilkan narasi kisah Panji - dengan latar belakang kultural spiritual orang biasa.

Keywords: mask, Malang, style, art creation, kidung, traditional, Panji | Topeng, Malang, gaya, penciptaan seni, kidung, tradisional, Panji

\section{Introduction}

In general, Malang mask art (seni topeng) is rooted in the Panji stories. It is also known as the Panji Tales which is often presented in the form of an art performance. The Panji story was written during the golden era of Majapahit (Kieven 2020: 90), as is evident from the reliefs on Kendalisodo and Panataran Temple in Blitar (Kieven 2014: 3) and the Gambyok Site in Banyakan Kediri (East Java) which portray scenes and images of Panji dating back to 1413 AD (Winstedt 1969: 53-4). The Panji story is considered to be a form of literary revolution against Indian traditions, which began during the golden Majapahit era and was written in the language of Jawa Tengahan (Middle Javanese) (Poerbatjaraka 1931: 408-409). The traditional status of mask art is affirmed in Pararaton and Negarakertagama which tell about King Hayam Wuruk performing a masked dance (1350-1389) (Suardana 2015: 80-94).

The form of Malang masks was 'produced' to express the different figures in the narration of the Panji story. The story of Panji tells of the romantic adventures of a prince and hero of the preIslamic era who aspired to the noble Javanese ideal of betterment, going against the odds, and ultimately attaining victory (Ricklefs 2013: 80; Forshee 2006:196). A prince from the Janggala Kingdom by the name of Panji Inu Kertapati (the incarnation of Kamajaya) and a princess from the Kingdom of Kediri by the name of Galuh Candrakirana or Sekartaji (the incarnation of Dewi Ratih) are the main figures in the story, and play key roles in the division of the kingdom after the death of King Airlangga (Kieven 2014: 39). In the Javanese tradition, the Panji story fills a historical gap in the period after the Airlangga era and is considered as wayang topeng (mask theater) artists in Malang to be based on historical truth (Andalas 2016: 2-3; Supriyanto and Pramono 1997: 11).

New episodes of the Panji story continued to be written until after the 19th century in Central Java, and this is connected with the frequency of wayang topeng performances in which Panji was the main character (Ras 2014: 226; Pigeaud 1938: 79-158). The Panji story is an example of classical Javanese literature which has had a broad impact on Javanese literature. It is said that from the oral form of this story, numerous myths and fairy tales were born, including Andhe-andhe Lumut, Kethek Ogleng, Timun Emas, Panji Laras, and so on, in addition to the stories used in other performing art forms such as wayang beber (picture scrolls), wayang gedhog (Panji wayang), kethoprak (traditional drama) (Supriyanto and Pramono 1997: 9), dance-drama, etc. Topeng Malang has its own typology of characters of the main figures in the story.

Topeng Malang was traditionally performed during the Singasari period at family events and at the time of milling in the factory (Pigeaud 1938: 142). This article is founded on a concern that the mask culture has entered into a period of decline. From the 1930s, traditional art observers such as 
Pigeaud and the Regent of Malang, Raden Adipati Surio-adiningrat, were pessimistic about the sustainability of the mask culture (Onghokham 1972: 111). This is in fact also the case in Yogyakarta, Surakarta, and Cirebon. Social and cultural traditions no longer support the existence of the mask culture, and the infrequency with which masks are used in traditional events has had implications on the activity of mask production itself. In addition to being used for figuration of roles in a performance, Malang masks are also art objects which possess visual characteristics that are interesting and vital to study, in order to learn about local knowledge, and at the same time to appreciate the status of the mask as a visual art tradition.

\section{Literature Review}

In Southeast Asia, masks are artefacts which are considered sacred objects that were once used in pre-Hindu animism rituals and magical performances as a form of homage to ancestral spirits. This practice is believed to have formed the foundation for the use of the mask in performing arts or theater in Java (Brandon 1967: 42, 45-46; Hughes-Freeland 2008: 38). In 882 AD masked dancers and shadow puppeteers were mentioned in the first Balinese inscription, and Napier (Emigh 1996: 79) proposes that the use of demon-like masks to project aspects of the Brahmanical god, and the consequences of the Hindu tradition for the interpretation of the masks, realized two things, namely "holy power" and "becoming great". This may have played a vital role in many aspects of these new gods, who were displayed in human form, portraying themselves as the manifestation of a holy and charismatic expression through ritual (Napier 1986: 190-193).

Masks, known in Java as kedhok and Bali as tapel, are used to cover a person's entire face (Suanda 1985: 84). Masks have an artistic value in that the communicative character of a particular mask cannot be separated from its use as part of the costume in a performance (Tonkin 1992: 225-232). Masks portray images of people, animals, or spirits, which are created, presented, or manipulated in a narrative or dramatic performance (Proschan 1983: 3-46).

The existence of wayang topeng, after the creation of the Panji story at the end of the $14^{\text {th }}$ century, became an art form which developed not only inside the royal court but also in village communities (Brandon 1967). Soedarsono states that wayang topeng is a development of rakèt, an art form that existed since the Majapahit era, and also explains that visually, masks are a transformation of the faces of three-dimensional puppets or wayang golek (Soedarsono 1997). According to Pigeaud, wayang topeng during the Islamic Mataram period (1584-1755) was a court performance that also spread extensively to coastal areas and areas outside the royal kingdom (Soedarsono 1997: 19). In Javanese Volksvertoningen, Pigeaud writes that in the 1930s, this kind of art was highly popular in the Javanese community (Pigeaud 1938: 141-147).

Malang has for a long time been recognized as the centre of the mask culture. "Kepanjen" is the place of origin of the Panji wayang (Pigeaud 1938: 141-147; Onghokham 1972: 111). In the Malang Regency itself, Pigeaud writes that in the 1930s there were 21 sets of masks, each set containing between forty and fifty masks. Pigeaud and the Regent of Malang at the time concluded their observations with a pessimistic view about the future of the wayang topeng tradition in Malang (Onghokham 1972: 111). Their pessimism was based on the fact that an increasing number of people were moving from one area to another and radio broadcasts were also beginning to harm local art traditions.

As an art phenomenon, the mask exemplifies two artistic domains - performing art and visual art. In performing art, the mask is a dance property. As a visual art phenomenon, the mask is a work of 
art (Tonkin 1992: 225) because it is a product of skill or handicraft. As a work of visual art, the mask is an artistic object which has a beauty of form. Through skill and craftsmanship, the visual manifestation of a mask refers to a number of things that are artificial (Bell 2010: 204), and in material terms, the mask has the ability to portray the image of human beings, animals, or spirits (Proschan 1983: 4). From the visual art perspective, the mask can be viewed as a craft artefact because of its practical use, but on the other hand it can also be conceived as an art object because of its expressive characteristics. Therefore, the mask is an artefact which has a dimension of practical function on the one hand and artistic function on the other.

The mask is a type of traditional Javanese visual art, in addition to batik, wayang kulit (leather puppets), wayang beber (picture scrolls), keris (dagger), tenun (woven cloth), anyaman (wickerwork), gerabah (pottery), ukir-ukiran (wood carving), ornaments, and so on. The traditionality of these arts points to the process by which they were passed down from one generation to the next. On the other hand, the details of this traditionality also refer to the material, technical, and contextual aspects. This means that the products of this art activity use materials of a traditional nature; materials that are found in the surrounding environment of the local community. Traditional techniques or methods are also used to create the product or object. And the product itself is used in a situation or context needed by the traditional community (Metcalf 1997: 70-71).

The mask tradition, both as a performing art and a visual art, can be found in several places in Malang, East Java. The north, south, east, and west districts of Malang are all loci of the mask culture. Places widely recognized for mask production include Kepanjen, Jabung (south Malang) and Polowijen (north Malang), while the village of Jenggala, in the Kepanjen Sub-district of the Malang Regency (in the south) is one of the places which is known to produce the best quality masks (Murgiyanto and Munardi 1979/1980: 23). In the past, Kepanjen was the name of the place where the Panji wayang or masks came from, and was widely known as the centre of the mask culture (Pigeaud 1938: 141-147; Onghokham 1972: 111). This art form, which was rooted in the pre-Majapahit era, continued to exist right up to the Islamic Mataram era and influenced the wayang orang culture in both Surakarta and Yogyakarta.

In ancient times, Malang was the place where the Panji stories were born; stories that constituted the main theme for stories of wayang gedhog, a mask art performance (Pigeaud 1938: 141). In general, the community of the Malang Regency can be grouped into three sub-communities, according to their social and cultural development. The first group is the community known as priyayi (officials or members of the upper class), who traditionally lived in the southern district of Malang and supported the growth of arts rooted in the keraton culture, especially the culture of the Surakarta keraton, and were also referred to as wong kulonan or "people of the west" (Hidayat 2004: 393-4).

The second group lived in the east part of the southern Malang district and were frequently referred to as wong gunung or "people of the mountain". They developed the arts in the post-Majapahit era, against a background of animistic beliefs, influenced by the Hindu and Buddhist religions, and subsequently gave rise to traditional performing art forms such as Sodoran, Ujung, Jaran Joged, and Tayub (Hidayat 2004: 393). Also included in this second group are the Madurese community who lived in the eastern district of Malang, and were a community of Madurese people who had assimilated with the (Javanese) people of Malang. Their descendants were referred to as wong Pendalungan and they created arts with an Islamic influence such as Hadrah, Barjanji, Terbang 
Jidor, Kuntulan, Pencak Silat, Samroh, and Sandur. In general, the wong Pendalungan community was also very fond of wayang topeng. Wayang topeng was used as a medium for ruwatan (exorcism) ceremonies because the medium of cowhide was not permitted to be used in this type of ritual, meaning it was not possible for wayang kulit to be performed (Hidayat 2004: 394). The third group is the people who lived in the western district of Malang. This community was influenced by the pre-Majapahit culture (Hidayat 2004: 394). The arts in this area were influenced by the culture from the time of the Kediri kingdom. The style of the arts had a Hindu-Javanese character, as seen in the art of wayang wetanan (wayang Jeg-dhong) and also the performance of Lerok, Bestuan, and Ludruk, which used the local Malangan dialect of Javanese. In addition, there was another art which is considered to have originated from the Malang district, namely wayang topeng. Wayang topeng is a dramatic art performance in which the story is presented through the dominant aspects of dance and the voice of the dalang (puppet master). This community, which supported the pre-Majapahit culture, lived in the area to the north of the Lesti River (Hidayat 2004: 394).

The second group lived in the east part of the southern Malang district and were frequently referred to as wong gunung or "people of the mountain". They developed the arts in the post-Majapahit era, against a background of animistic beliefs, influenced by the Hindu and Buddhist religions, and subsequently gave rise to traditional performing art forms such as Sodoran, Ujung, Jaran Joged, and Tayub (Hidayat 2004: 393). Also included in this second group are the Madurese community who lived in the eastern district of Malang, and were a community of Madurese people who had assimilated with the (Javanese) people of Malang. Their descendants were referred to as wong Pendalungan and they created arts with an Islamic influence such as Hadrah, Barjanji, Terbang Jidor, Kuntulan, Pencak Silat, Samroh, and Sandur. In general, the wong Pendalungan community was also very fond of wayang topeng. Wayang topeng was used as a medium for ruwatan (exorcism) ceremonies because the medium of cowhide was not permitted to be used in this type of ritual, meaning it was not possible for wayang kulit to be performed (Hidayat 2004: 394).

The third group is the people who lived in the western district of Malang. This community was influenced by the pre-Majapahit culture (Hidayat 2004: 394). The arts in this area were influenced by the culture from the time of the Kediri kingdom. The style of the arts had a Hindu-Javanese character, as seen in the art of wayang wetanan (wayang Jeg-dhong) and also the performance of Lerok, Bestuan, and Ludruk, which used the local Malangan dialect of Javanese. In addition, there was another art which is considered to have originated from the Malang district, namely wayang topeng. Wayang topeng is a dramatic art performance in which the story is presented through the dominant aspects of dance and the voice of the dalang (puppet master). This community, which supported the pre-Majapahit culture, lived in the area to the north of the Lesti River (Hidayat 2004: 394). 
Fig. 1 Handoyo performing the Bapang Mask Dance. Source: Photo by R.M. Pramutomo.

In the past, the village of Polowijen, which was situated to the north of Malang, on the road to Surabaya, was the centre of mask art (Onghokham 1972: 111). Today, the village of Polowijen is better known as the village of Reni, named after a farmer by the same name, who in the 1930s was renowned as the greatest Malang-style mask sculptor. His wayang topeng group was also one of the best groups around, and helped bring wayang topeng to the peak of its existence. These developments were also related to the patronage of the Regent of Malang at that time, R.A.A Soriaadiningrat, who provided the necessary materials (gold leaf, good quality paint, and wood) for ensuring an artistic standard with perfect proportions, refined carving, and skillful coloring). In Malang, Reni’s masks are considered to exemplify the classical standard of the art (Onghokham 1972: 120).

\section{Theoretical Foundations and Research Method}

The status of the Malang masks used in the Panji stories is not spiritual masks that are derived from the culture of animism but rather narrative masks which are an element of a story or narration during the Hindu-Javanese Period. This means that the cultural background of the mask, with specific reference to Panji as the subject of the study, is motivated by spirituality based on Hinduism, an adaptive religion with a hierarchical structure (Napier 1986: 190). The appearance of the mask was later to become different from the "primitive" mask used in pre-Hindu animism rituals. The narration in the period of power, for example in the Airlangga era (1011-1049 AD), provides the setting for the Calon Arang story - the most frequent narrative context for Rangda's appearances (Emigh 1996: 79). The dissemination of Indian culture in Indonesia has been recognized through the use of the mask in performing - during the adaptive Hindu era - with wellprepared continuity of mask iconography in ritual, mostly visible in temples and reliefs. The Kala- 
makara mask is a Hindu archway figure elaborated in Java - reminiscent of another Balinese figure - Rangda (Moore 1977: 135).

Literary sources on masks date back to the fourteenth century (1365) Hindu era, in the Javanese panegyric about King Hayam Wuruk of Majapahit (East Java), The Nāgara-Kertāgama, which describes the inclusion of raket in Java, an art that has been interpreted as a "mask play" (Pigeaud 1962: 345). A dichotomy followed between the two genres kakawin (Indian-based stories written in Old Javanese) and kidung (written in a metre independent from Indian poetry, using Middle Javanese). Similar to kakawin, kidung are set in a court environment but they have a stronger Javanese setting (Kieven 2013: 23). The flow of literacy connected to the mask transformation is indicated by kakawin becoming the unit of narration which has a religious purpose, namely to achieve the Divine, while kidung (indigenous stories) are more related to daily life (Kieven 2013: 30). Using this dichotomy, Kieven argues that the Panji stories are "post-mythological stories" because of Panji's encounter with the people and their strong sense of appeal to an average audience, and that they represent one conspicuous example of Majapahit's creativity; to display the simple life of the common people, thus transferring the folk character of the literary versions (Kieven 2017: 2-9; 2020: 72). The Javanese could identify the heroes of the 'lunar race', engaged in an internecine fraternal war, with their own mythical ancestors - this explains the often grotesque changes which the Indian stories suffered in the process of adaptation. Only those elements of the original stories which were assimilable to the Indonesian myth were accepted, the rest were either changed or left out altogether (Ras 1973: 429). Panji stories may posit that Java must also have passed through a stage of totemism, that especially the Panji myth belongs to a totemistic environment, and consequently developed out of a totemistic rite (Ras 1973: 431).

Despite being the properties of an art performance, these masks are also works of visual art (Tonkin 1992: 225) because they are a product of skill or craftsmanship. Whether consciously or not, mask makers cannot break free from various assimilations of influence, and visual images that are culturally specific (Bell 2010: 18). This article aims to identify in depth the characteristic or style of Malang masks, and to describe the existence of the art of mask craftsmanship in Malang. The approach used in this study is the stylistic side of creation which focuses on visual elements and the elements that form the character of the mask itself.

According to Leonard B. Meyer, style is the replication of a pattern, whether in relation to human habit or in an artefact produced by human habit, created as a result of a series of choices with various limitations, which are studied and adopted as part of the historical-cultural circumstances of an individual and group, and which enable various realizations of the pattern that are not necessarily the same as its collective replication. Style depends on synonymity existing between the masks, which results in their identification and classification. The replicated patterns found in works of art become general principles. An analysis of style begins with a description and classification, with a number of examples that can illustrate the facts (an essential hypothesis) (Meyer 1987: 21-33). In other words, the characteristics of the work described become essential symptoms for the presence of a style.

The general characteristics that shape a particular style (Goodman 1978: 25) are limited in this study to the form, expression, and function of the masks - which create the unique style of production of the group of traditional mask artists in Malang, while not ignoring the Panji story as the source of representation. This is founded on the logic that Malang masks are art objects with an artistic form which supports the representation of the different figures in the Panji story. The focus of the analysis of visual characteristics is the aspect of creation through the identification of 
typology of character in the facial elements of the mask, and the socio-cultural background of the mask makers. In order to address these questions, the idea proposed by Meyer Schapiro - namely that style is a constant form or element, a quality, and an expression in an art of an individual or a group (Schapiro 1953: 287) - is the tool used to determine synonymity between the mask forms.

An additional discussion focuses on the artistic form of Malang masks, viewed in terms of production in this area, specifically masks originating from the Panji story. The form of Malang masks as products of traditionality is viewed in terms of material, technique or method, and context of use in the community (Metcalf 1997: 70-71). The data collection began with a library study, followed by interviews and documentation. The library study was carried out by searching written sources in order to obtain information about the existence of the mask art in and around the Malang area in the past. This information was needed to learn about the historical aspect of the mask production centre in this area. The information obtained from the library study was used more as a way of confirming the existence of the production centre of Malang masks in the present day. In short, this essay aims to describe in a qualitative manner the artistic phenomenon of the Malang mask from the point of view of the tradition of its creation.

\section{Discussion}

In general, Malang masks have conceptual form, carvings, decorations (sunggingan), and colorings. In the community, the mask as an element of wayang topeng is a unit to display characterization, identified by act, speech, thought, physical structure - to "create" a figure which determines the role of play, mostly determined by physiological, sociological (community life) and psychological features (Supriyanto and Pramono 1997: 23).

There are four main groups of mask character. The first group represents the figure of Panji with the characteristics of a handsome young man who has a noble, gallant character. The second group is the antagonistic figures, characterized by large, round eyes and protruding fangs. The third group represents the figures of servants with comical ornaments in the carving. The fourth group is the animals who are the additional figures in the story (http://ngalam.id/read/4071/topeng-malangan/).

The facial characterization in the Malang masks can be equated with the concept of humanity, and subsequently gave rise to several different kinds of form and groups of character. To elaborate further, the Malang mask art consists of \pm 76 masks that can be divided into 8 categories: (1) gods; (2) priests; (3) kings; (4) regents (5) strong masculine characters; (6) refined characters; (7) female characters; (8) punakawan (clown servants) (Murgiyanto 1979/1980: 96). One of the Malang mask shapes considered to be most unique is that of Klana Bapang which has a very long nose. Another characteristic of Malang masks is that all the figures in a performance, whether or not they are performing on stage, have an ornamental headpiece carved onto the mask itself (Pigeaud 1938:147). 


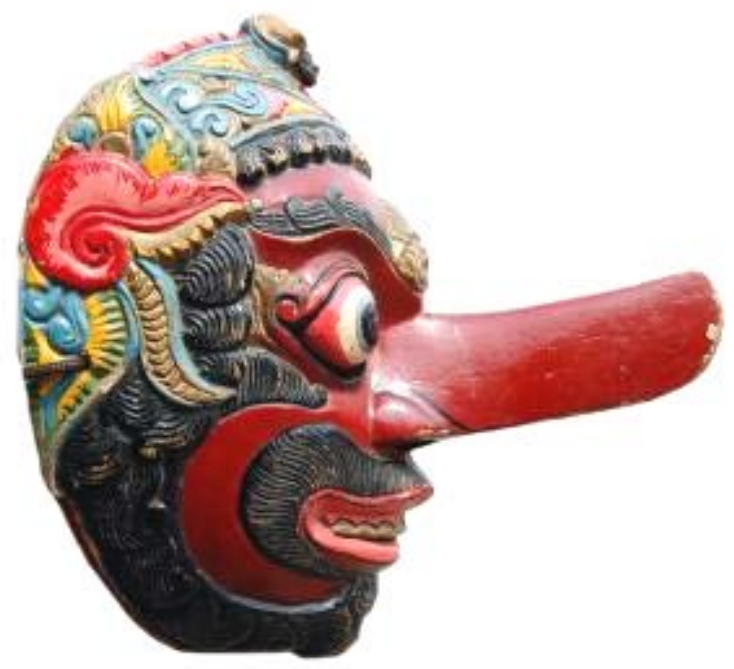

Fig. 3 A Bapang mask characterized by a very long nose. Source: Photo by Guntur and Nurohim.

The characteristics of Malang masks are not only presented by the shape of the face but also by the choice of color used for the characterization of the different figures. There are four main colors used for this characterization: white for the virtuous, noble characters; red for relentless, courageous characters; black for wise characters who are free of all worldly desires; and yellow gold for characters who are graceful or authoritative. In addition, other colors such as green, blue, orange, and brown are used for portraying other characteristics. The combination of shapes and colors creates masks with a variety of different characteristics. The mask of Panji portrays the character of a person who is wise, discerning, and humble. The Bapang mask depicts the character of a knight who is bold and roguish. The mask of Klana portrays a character who is greedy. 

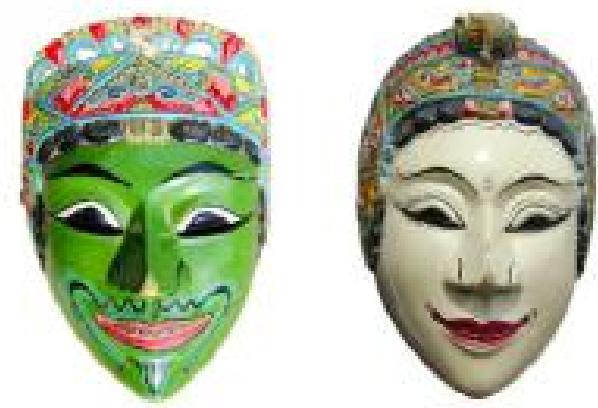

Panji Asmoro Bangun and Dewi Sekartaji
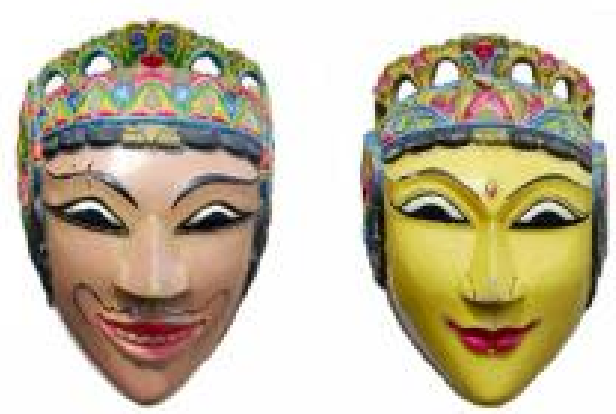

Panji Banyaksasi and Dewi Ragil Kuning
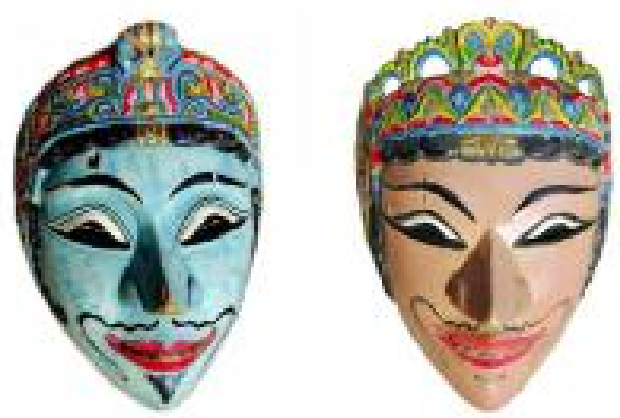

Panji Pambelah and Panji Walang Semirang
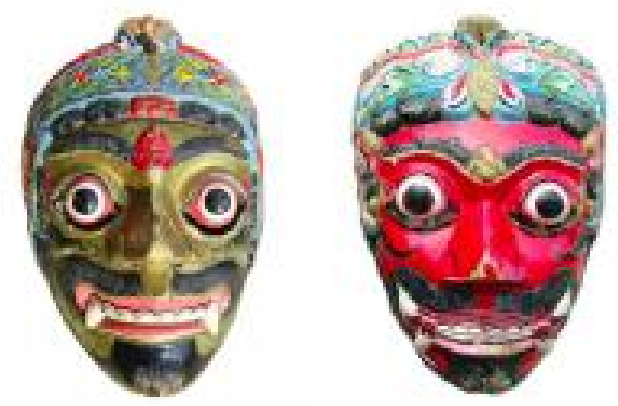

Patih Gajah Meto and Patih Kollo Memreng
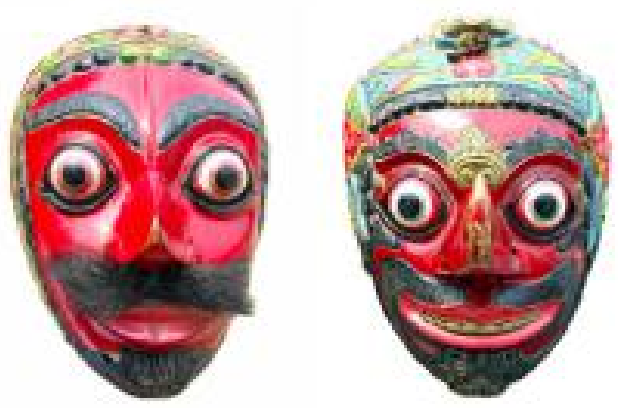

Klana Sewandana and Bapang Jaya Sentika
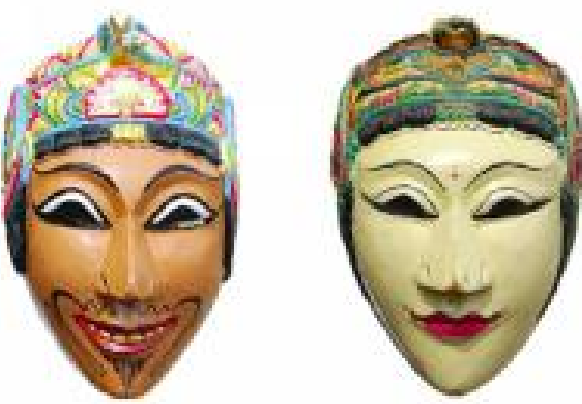

Panji Amerdadu and Dewi Walang Wati
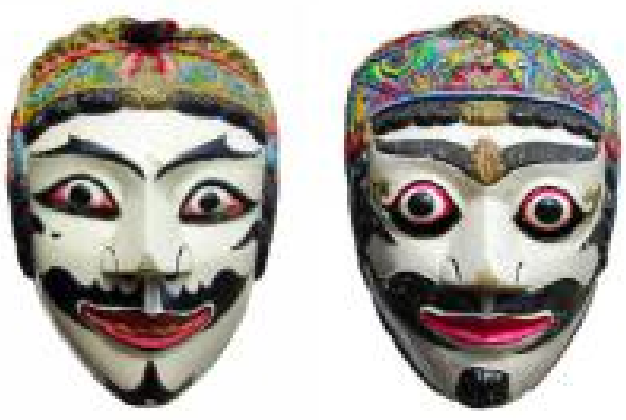

Brajanata and Musing Jiwo
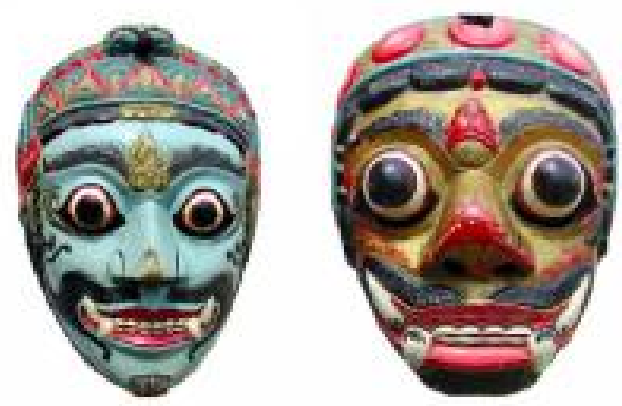

Patih Kraeng Projo and Kollo Tekik Sologonjo

Table 1. Selected Malang mask characters (continued in next page). Source: Photo by Guntur and Nurohim. 

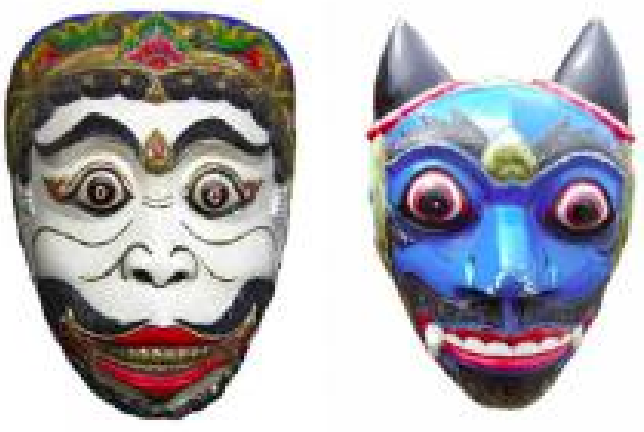

Bedes and Mahesa Sura
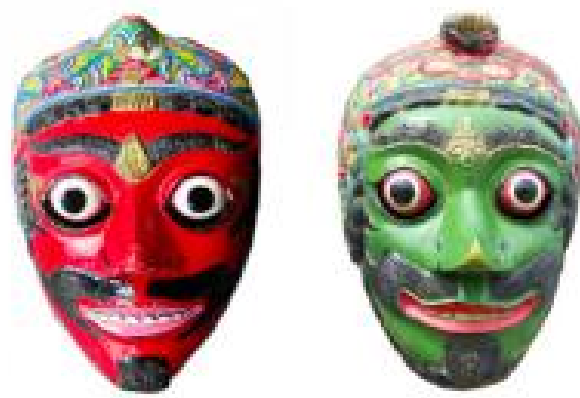

Patih Dandang Mangkurat and Udapati Kartolo
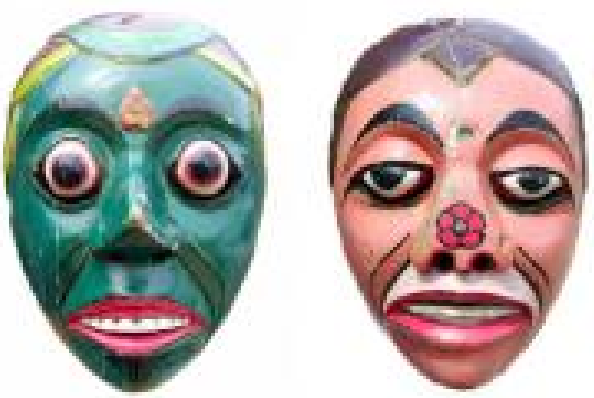

Demang Mones and Demang Mundu
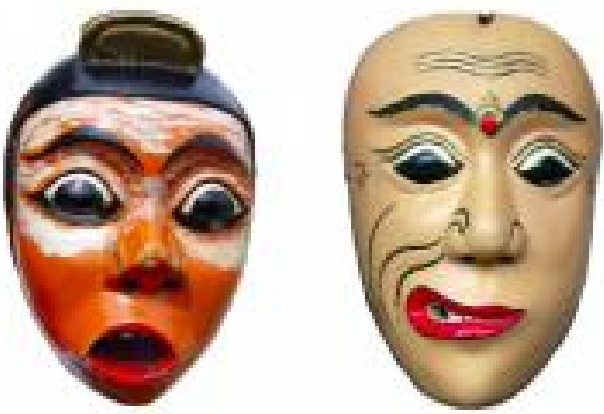

Emban Dawolo and Bilung
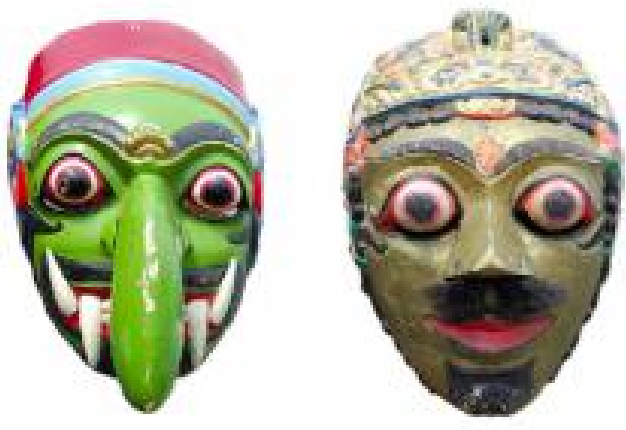

Buto Terong and Klana Baron Sakeber
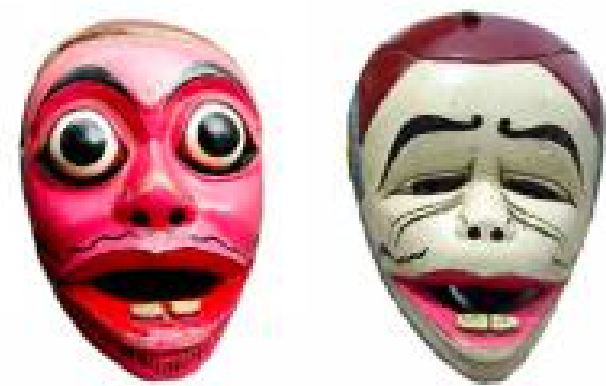

Prasonto and Jarodeh
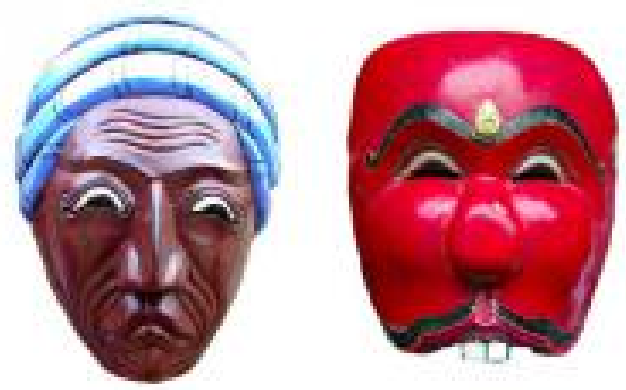

Begawan Walang Dewa and Raden Patrajaya

Table 1. (continued) Selected Malang mask characters. Source: Photo by Guntur and Nurohim. 


\section{Form as typology of character}

Form has a number of visual characteristics such as size (length, width, thickness), color, and texture. The form of a mask is an adaptation of the overall form of the human face which is interpreted through the work of the artist who sculpts and decorates the mask. A mask is the product of sculpting and decorating with various lines and colors. The lines express the impression of the mask figure's character. Straight lines are used for characters with an upturned face (lanyap), curved lines for refined characters, and sharp, rough lines for strong, masculine characters.

Different colors are used to express the symbolic value of the mask figure. Red is used to portray arrogant, evil, bold characters. White is used for the figures of knights who are pure, refined, and noble. Black is used to portray figures who are wise, discerning, and unwavering in battle and service.
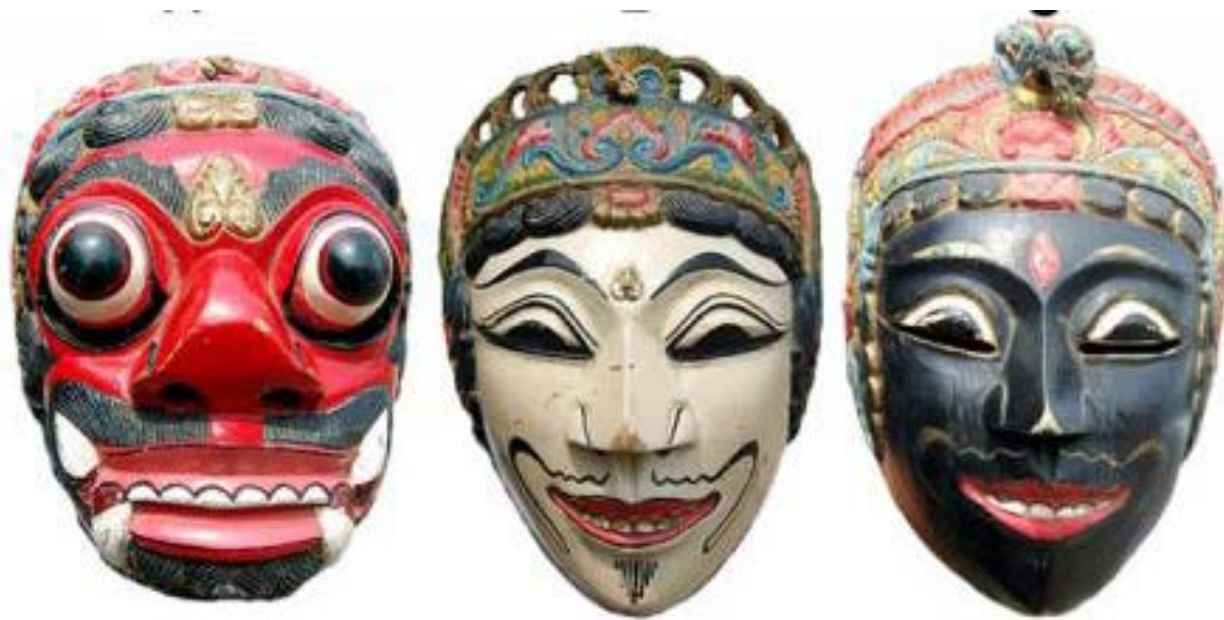

Fig. 4 Typology of masculine characters in the Malang mask style, from left to right: Kollo Marko Mamang, an arrogant, evil character; Gunung Sari, a refined, noble character; Tokoh Panji Lembu Amijaya, a wise, discerning character. Source: Photo by Guntur and Nurohim.

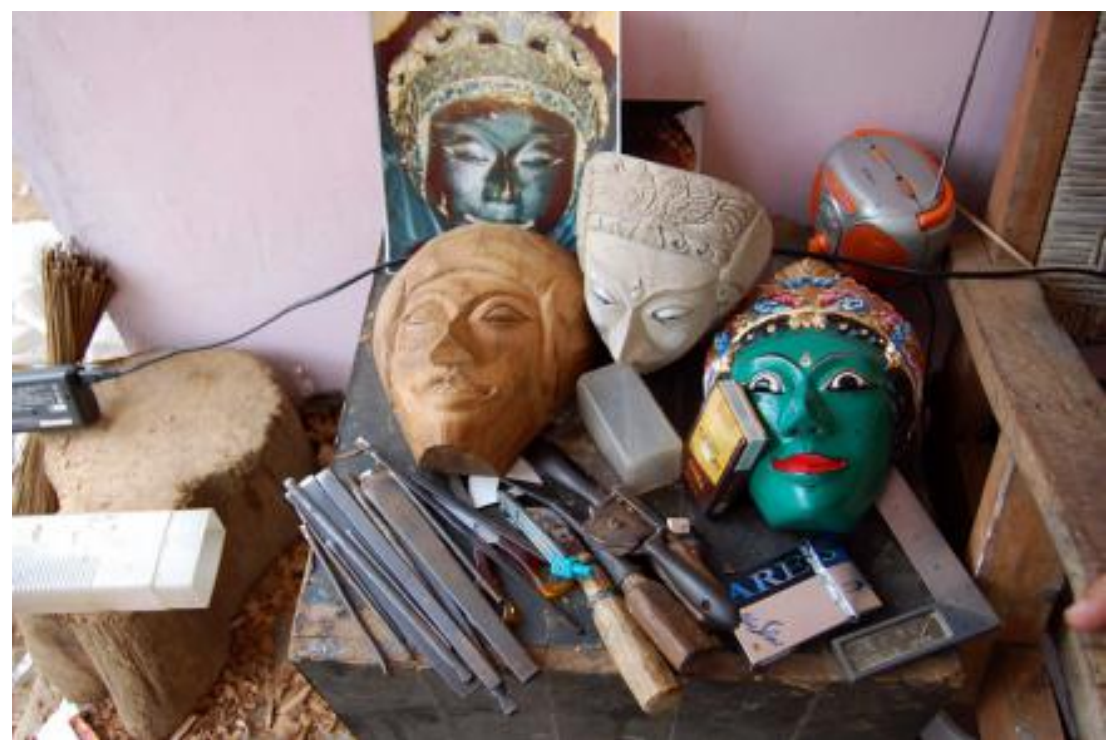

Fig. 5 Tools, materials, and master mask (babonan), used as a reference in mask making. Source: Photo by Guntur and Nurohim. 
A mask is the personification of human qualities and human characters, and the overall facial expression of a mask is similar to that of a human face. Certain features (eyes, nose, and mouth) are emphasized or made more prominent in order to strengthen the characterization of the particular figure. This emphasis on form can be seen in the lines of the eyes, nose, and mouth, which display different characteristics in shape from one figure to another. The character of liyepan-shaped eyes is different from the shape of thelengan eyes, and this is also true for the different shapes of the nose and mouth. Below is a visual grammatical explanation of the different shapes of eyes, noses, and mouths.

\begin{tabular}{|c|c|}
\hline & $\begin{array}{l}\text { Liyepan } \\
\text { The eye is shaped like a grain of rice, as though sleepy. The black part of } \\
\text { the eye is at the bottom, creating a bold, assertive impression. This eye } \\
\text { shape is usually used for refined characters such as the figures of Panji } \\
\text { (knights), Dewi (princesses), and Raden (noblemen). The character of mask } \\
\text { figures with liyepan eyes is honest, patient, gentle, and gallant. }\end{array}$ \\
\hline & $\begin{array}{l}\text { Blalakan } \\
\text { In this wide-eyed shape, the whole eyeball is visible but the eye is not } \\
\text { completely open. This shape is used for strong, masculine knights such as } \\
\text { Brajanata, Patih Ngaronggo Kusumo. The character of mask figures with } \\
\text { blalakan eyes is gallant, agile, honest, strong and brave. }\end{array}$ \\
\hline & $\begin{array}{l}\text { Kriyipan } \\
\text { This shape is like an eye that is squinting from exposure to bright light and } \\
\text { only } 3 / 4 \text { of the eyeball is visible. Mask figures with this eye shape include } \\
\text { guardian servants (punakawan), such as Jarodeh and Patrajaya. The } \\
\text { character of mask figures with kriyipan eyes is devoted, humorous, honest, } \\
\text { and loyal. }\end{array}$ \\
\hline & $\begin{array}{l}\text { Pananggalan } \\
\text { The eye is shaped like a crescent moon, looking downwards like the eye of } \\
\text { an elderly person. This shape is used gods and holy men such as Narada, } \\
\text { Begawan Walang Dewa, Begawan Gajah Abuh. The character of mask } \\
\text { figures with pananggalan eyes is authoritative, prescient, discerning, and } \\
\text { noble. }\end{array}$ \\
\hline & $\begin{array}{l}\text { Thelengan } \\
\text { This eye shape is like that of an angry person with bulging eyes, the eye is } \\
\text { completely open and the whole eyeball is visible. This type of eye is used } \\
\text { for the figures of Klono, Bapang, Patih, Panji gagahan, such as Klana } \\
\text { Sewandana, Bapang Jaya Sentika, Patih Sura Dwipangga, Panji }\end{array}$ \\
\hline
\end{tabular}




\begin{tabular}{|l|l|}
\hline & $\begin{array}{l}\text { Gurawangsa. The character of mask figures with thelengan eyes is strong, } \\
\text { brave, tough, and gallant. }\end{array}$ \\
Plelengan \\
This eye shape is large and round, with the eyeball protruding from the \\
socket. This shape is used for giants and wild animals, such as Kollo Tekik \\
Solongonjo, Nogo Tahun. The guardian servant Prasonto also has plelengan \\
eyes. The character of the mask figures with this eye shape is strong, \\
courageous, arrogant, and angry, and the character of the guardian servant \\
Prasonto also has an element of humour.
\end{tabular}

Nose Shapes

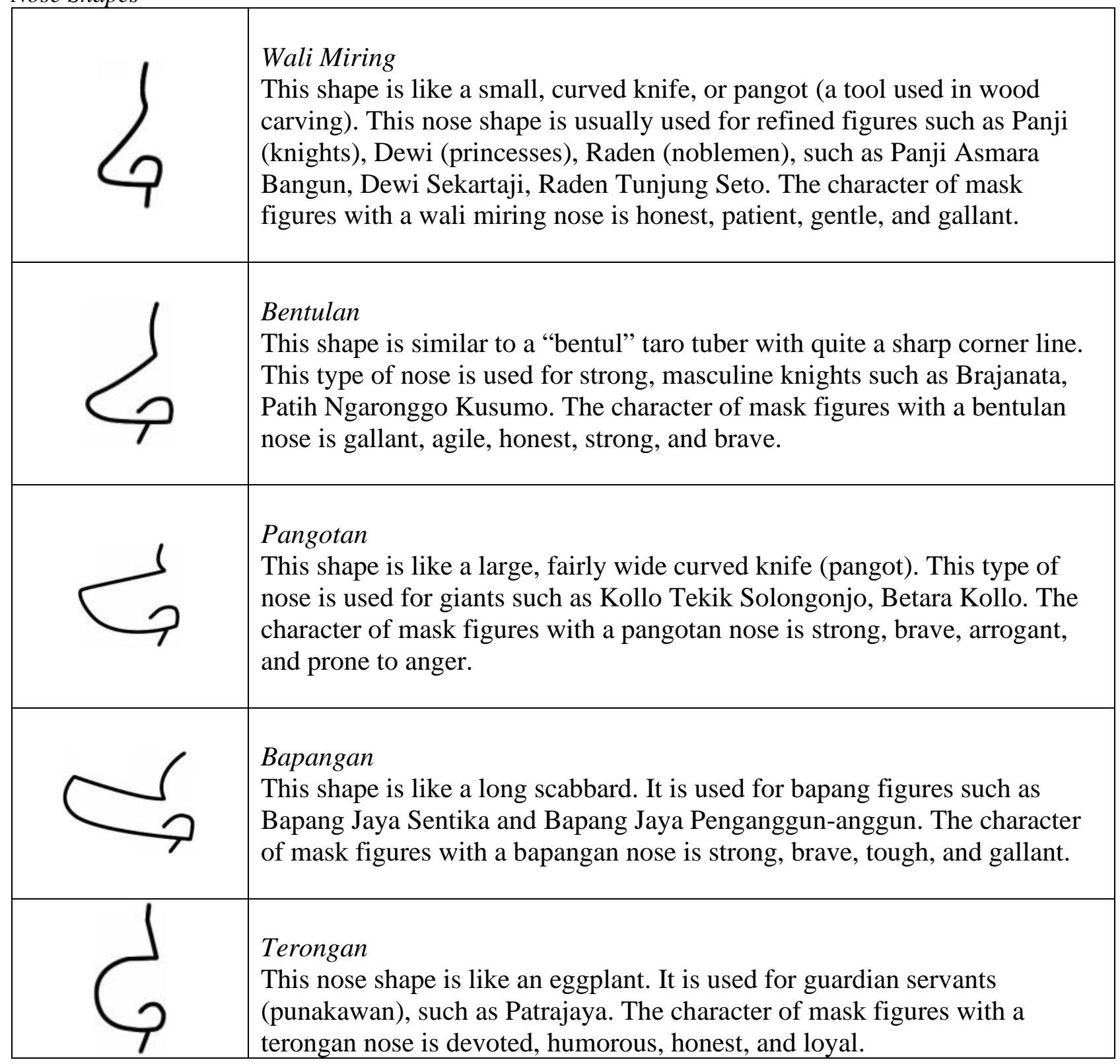




\begin{tabular}{|l|l|}
\hline & $\begin{array}{l}\text { Pesekan } \\
\text { This type of nose is very small, flat, and appears to go inwards. This shape } \\
\text { is used for monkeys, guardian servants (punakawan), such as Bedes and } \\
\text { Jarodeh. The character of mask figures with a pesekan nose is devoted, } \\
\text { humorous, honest, and loyal. Specifically in the case of Bedes, the character } \\
\text { is courageous and agile. }\end{array}$ \\
\hline
\end{tabular}

Mouth Shapes

\begin{tabular}{|c|c|}
\hline & $\begin{array}{l}\text { Terkatup } \\
\text { The mouth is closed and smiling, shaped like a boat. This type of mouth is } \\
\text { used for the figures of klono, patih, and kesatriya, such as Klana } \\
\text { Sewandana, Patih Musing Jiwo, Lembu Suro. The character of mask figures } \\
\text { with a terkatup mouth is strong, brave, tough, and gallant. }\end{array}$ \\
\hline & $\begin{array}{l}\text { Terkatup Putren } \\
\text { The mouth is closed and smiling, and the slight curve of the bottom lip } \\
\text { creates a sensual impression. This mouth shape is reminiscent of the } \\
\text { "tandak ludruk" makeup of ludruk performers, in which the lips are made to } \\
\text { look more sensual. This type of mouth is usually used for the figures of } \\
\text { Putren, such as Dewi Sekartaji, Dewi Kili Suci, Dewi Ragil Kuning. The } \\
\text { character of mask figures with a terkatup putren mouth is honest, patient, } \\
\text { and gentle. }\end{array}$ \\
\hline & $\begin{array}{l}\text { Prengesan } \\
\text { The mouth is slightly open and the upper teeth are visible, as though the } \\
\text { person is laughing. This type of mouth is usually used for refined figures, } \\
\text { Panji, Raden (noblemen), such as Panji Asmara Bangun and Raden Tunjung } \\
\text { Seto. The character of mask figures with a pregesan mouth is honest, } \\
\text { patient, gentle, and gallant. }\end{array}$ \\
\hline & $\begin{array}{l}\text { Gusen } \\
\text { The mouth is slightly open and the top teeth and canines are visible. This } \\
\text { type of mouth is used for giants such as Kollo Tekik Solongonjo. The } \\
\text { character of mask figures with a gusen mouth is strong, brave, arrogant, and } \\
\text { prone to anger. }\end{array}$ \\
\hline & $\begin{array}{l}\text { Pewekan } \\
\text { The corners of the mouth are turned down as though the person is crying } \\
\text { (mewek). This type of mouth is used for gods and holy men, such as } \\
\text { Narada, Begawan Walang Dewa, Begawan Gajah Abuh. The character of }\end{array}$ \\
\hline
\end{tabular}




\begin{tabular}{|l|l|}
\hline & $\begin{array}{l}\text { mask figures with a pewekan mouth is authoritative, prescient, discerning, } \\
\text { and noble. }\end{array}$ \\
\hline $\begin{array}{l}\text { Prongosan } \\
\text { The open mouth shows the protruding upper teeth without a bottom lip. } \\
\text { This type of mouth is used for guardian servants (punakawan), such as } \\
\text { Patrajaya. The character of mask figures with a prongosan mouth is } \\
\text { devoted, humorous, honest, and loyal. } \\
\text { (Re-designed by Nurohim) }\end{array}$ \\
\hline
\end{tabular}

\section{Facial Expressions in Malang Masks}

The facial expression in Malang masks can be seen in the shape of the face, the coloration, and the linear motifs of each figure. Most Malang masks have an oval-shaped face with a slightly pointed chin for the refined (alusan) and female (putren) figures and a more square-shaped chin for the stronger, masculine figures. Each individual sculptor has his own unique style. For example, the masks made by the late Karimun from Kedungmangga (Kedungmonggo) will differ from those made by Parjo Jabung. One of the characteristics of Karimun's masks is that the oval-shaped face has curved edges and a slightly pointed chin for the refined figures, while the stronger, rougher figures have a more square-shaped chin, while still retaining a balanced, curved outline. Parjo's masks differ in that they are all oval in shape, but the curved outline comes to a halt at the chin, which is not pointed but square-shaped, giving the impression of a flat, trapezium-shaped face. The differences between these and other craftsmen does not detract from the character of the mask itself. The character and personality of a mask can be viewed as a whole from all its elements, including the shape of the face, the eyes, nose, mouth, and color.
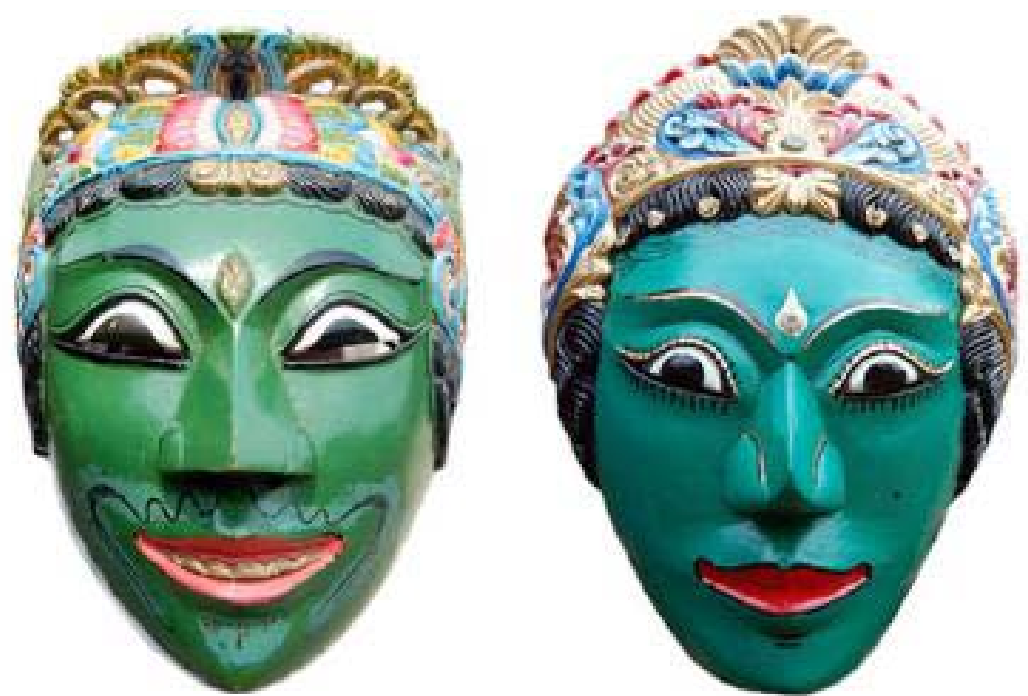

Fig. 6 Different shaped chins (janggut). Left: The work of the late Karimun from Kedungmangga and (right:) The work of Parjo Jabung. Source: Photo by Guntur and Nurohim. 
The majority of Malang masks have relatively large, wide-set eyes. Masks with blalakan and thelengan eyes in which the position of the black part of the eye is in the middle, between the upper and lower lines of the eye, creates an expressive impression. A curved line combined with a straight line gives a calm impression, while a curved line combined with a round arch gives an impression of dashing masculinity. The thelengan shaped eyes are usually used for strong, masculine figures such as Klana Sewandana, Lembu Sura, Bapang Jaya Sentika, and so on. The eye shape known as pananggalan is like a crescent moon with the upper and lower lines curving downwards and the black part of the eye at the bottom, like in an elderly person. This shape is used for gods and holy men such as Narada, Begawan Walang Dewa, Begawan Gajah Abuh. The character of these mask figures is authoritative, prescient, discerning, and noble. The various shapes of eyes are usually balanced by particular shapes of nose and mouth, in accordance with the character of the mask figure itself.

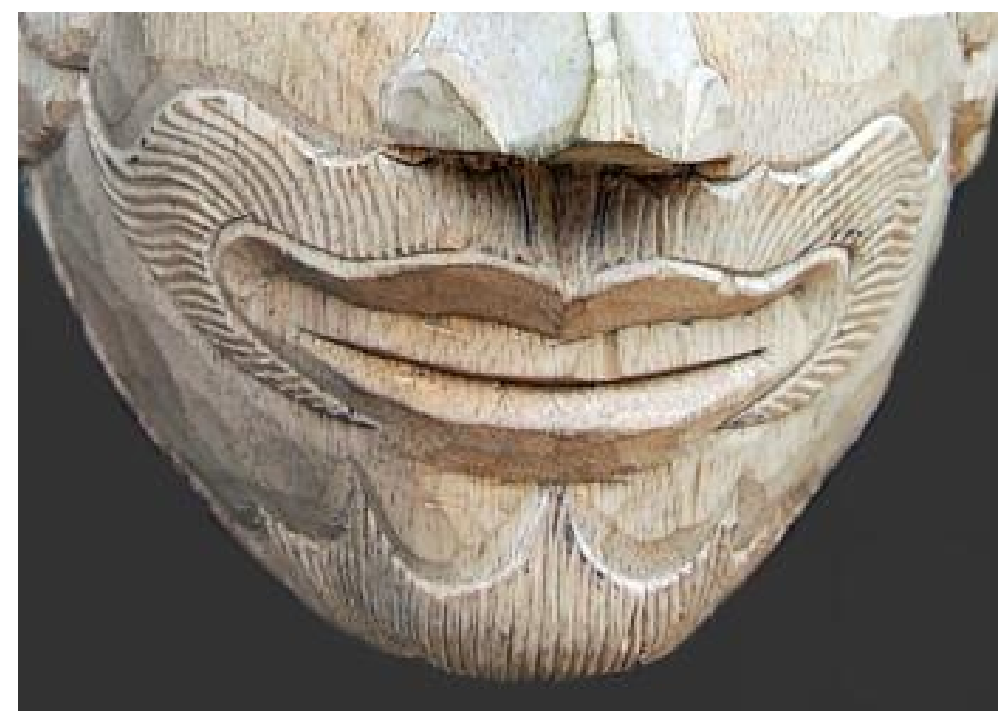

Fig. 7 Characteristics of keretan (carved lines), made with a special knife (pangot), to create a boundary between the mouth and moustache. Source: Photo by Guntur and Nurohim.

The shape of the straight lines and curved lines created by a small carving knife (pangot) creates a clear boundary between one part of the face and another. The carved lines (keretan) made by the pangot create a boundary between the eyebrows, eyes, nose, mouth, moustache, side-burns, hair, and headpiece. These lines are made particularly clear for the strong, masculine figures to create an impression of strength in the mask. The power of the lines supports the characterization of the different mask figures, as does the choice of color which is based on the typology of the characters.

Color is a symbol which portrays the character and personality of the mask figure. For example, white is used to portray an honorable knight who is still young, yellow portrays a female character (princess), duck-egg blue portrays kindness, dark yellow portrays stubbornness and arrogance, red portrays arrogance and courage, light pink portrays harshness and pride, pink portrays a stubborn heart, dark blue portrays magic, dark green portrays magic in a female figure, golden yellow portrays a knight still living in the court environment, dark brown portrays a faithful and roguish servant, and black portrays wisdom and persistence in battle.

\section{The Function of Malang Masks}

In former times, masks were often used in ceremonies practiced by animistic communities and were closely associated with the impersonation of spirits using a human medium. In the event of a death, the family left behind would create objects or images that could act as a "home" for the spirit of the 
deceased, so that at a certain time and in a certain way, this spirit could appear in their midst. The manifestation of these objects as the "homes" of spirits was accompanied by the composition of aesthetical forms such as the form of a leather shadow puppet or a mask (Murgiyanto 1979/1980: 19-20).

Nowadays, the function of masks is directed more towards practical concerns. Masks serve to express the character of the figures portrayed in a dance. The existence of Malang masks is still closely tied to wayang topeng and the art of mask dance which are performed by local communities and government institutions, such as art schools, in East Java. Wayang topeng is often performed at various events as a medium for ceremonies, festivals, and entertainment for the general public. These performances of wayang topeng can be enjoyed at village cleansing events, or sadranan, as well as at circumcisions, weddings, exorcisms, and on important feast days. Similar to wayang kulit, wayang topeng are stored tidily in a large box so that they can be transported to wherever the wayang topeng performance is to take place. The number of masks in a box varies, as does the type of mask figures and characters.

In addition to functioning as a performance medium, Malang masks are also decorative objects. Today, many mask sculptors are beginning to create miniature mask figures of various sizes that can be used as souvenirs. These come in many forms, such as wall decorations and key rings.

\section{Techniques and Materials for Mask Making}

The materials most often used for making masks in the Malang area are types of dense fibrous wood which do not easily break, such as kembang kenanga, pule, mentaos, waru, and cangkring wood. Kembang kenanga is frequently used in the Kedungmangga district because it grows widely in this area. Pule is the best kind of wood for mask making because it is easy to polish and has a bitter taste, meaning it is not the target of termites.

The wood used for making masks is usually quite old and comes from a tree with a diameter of \pm 30 $\mathrm{cm}$. After chopping the tree down, the wood is cut and dried in the open air out of direct sunlight so that it dries out properly and does not easily crack. If the wood is to be stored, rather than used directly, it should be dried out by storing it in the shade, wrapped in plastic to keep it moist, so that the drying process can take place slowly.

After the wood for making the mask has been cut to a size of $\pm 35 \mathrm{~cm}$ (the size of a face) and dried, its bark is then removed and it is cut into two pieces. A model for the mask is then made using an adze to create a rough pattern for the mask figure that is to be created. After that, the wood is carved using a pair of compasses to create a balanced shape, and shaped in more detail with a pangot to create the forehead, eyes, nose, cheeks, mouth, and chin. After the face is finished, the back of the mask is hollowed out to fit the shape of a person's face, using a small adze. The size of the indentation depends on the mask figure, whether it is male or female, so that it will be the right size for the person wearing it. The mask at this stage is known as the bakalan. 


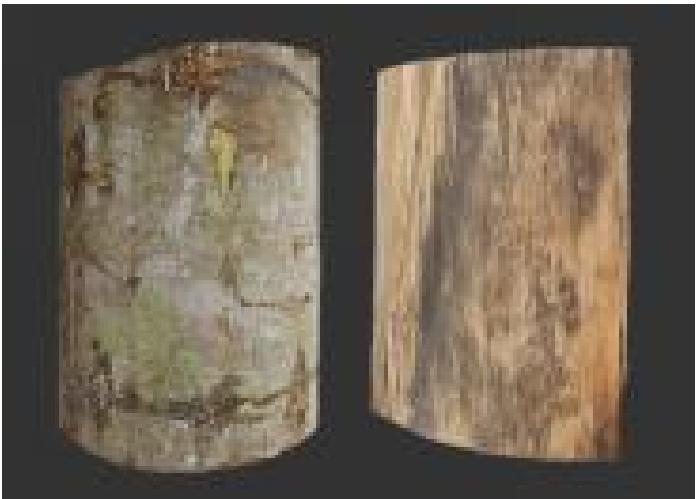

Kembang kenanga wood

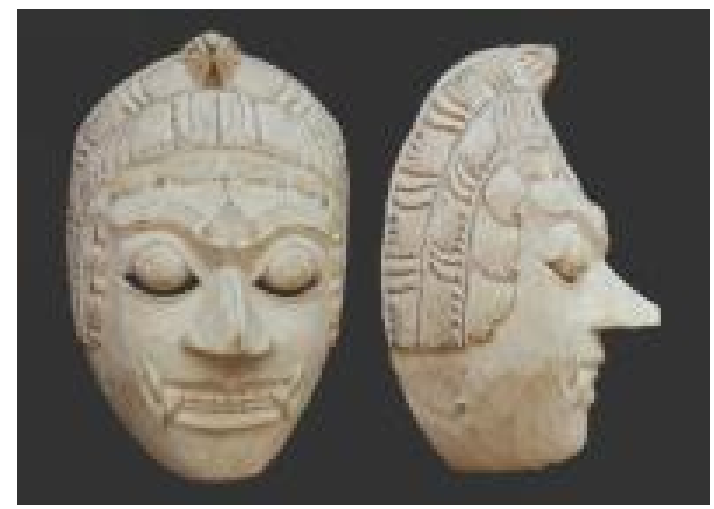

Calon (basic mask shape)

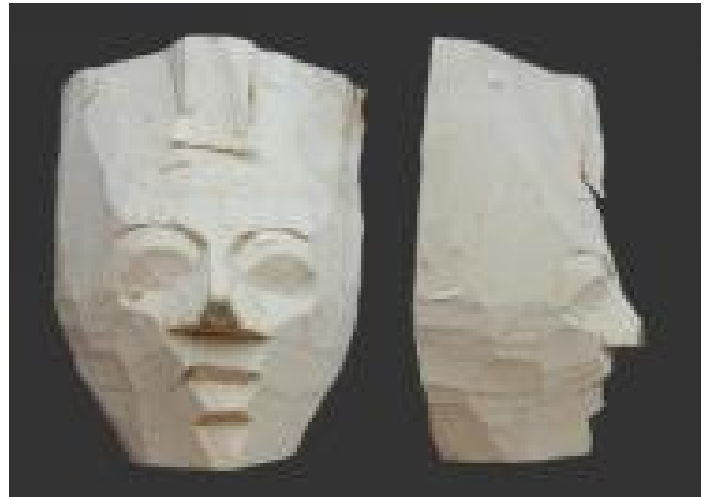

Mask model (bakalan)

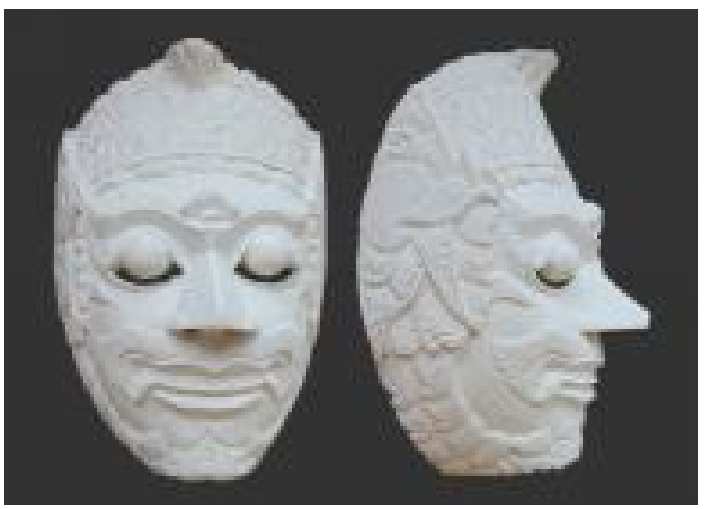

Mentahan (undecorated mask)

Fig. 8 Summary of the process of making a Malang mask. Source: Photo by Guntur and Nurohim.

The bakalan mask is processed further (dicaloni), by shaping certain parts in more detail by carving and sculpting with the use of various tools. The eyes are round-shaped if the mask is for the figure of Klono, and the side-burns, headpiece, hair, mouth, teeth, nose, and eyes are all carved in great detail and then smoothed using sandpaper to create the "raw" mask or mentahan. The mentahan mask is painted white and then decorated intricately or applied with gold leaf in accordance with the particular figure. The figure of Klana uses the color red, while Panji and Sekartaji use lighter colors such as white, yellow, light blue, and pink. The color is chosen to suit the wanda (shape, outward appearance, expressing various moods or emotions of the character) and character of the figure, based on its category. Both wood paint and metal paint are used to color the mask, applied with a small brush (numbers $1-12$ ), usually used for painting a picture.

The mask is then given additional features, such as a moustache for figures like Klana, made from black goat hair or the fur of another animal. The final stage of the mask making is to fit the mask with a string, attached to three points - top, left, and right - which is used to fasten the mask to the head of the person wearing it.

\section{Mask Making Tradition in Malang}

The tradition of mask making in the past centered on passing down carving or sculpting skills from parents to children. When a child truly had no interest in continuing the tradition, the mask maker would then pass on his skills to another interested or talented younger person. In connection with mask making, this factor affected the quality of the masks created. Another custom in the art of the mask was that the owner of an art studio was usually also a person who was skilled in the art of 
mask making. Mask dancers were also often in charge of studios or communities and by practicing the art of the mask, they also became skilled mask makers.

In the past, mentaos wood was frequently used for making masks. Other types of equally light wood that can also be used for making masks includes kweni, pelem, sentul, and kemiri wood. However, the wood of choice is mentaos because it is light, has fine fibers, is easy to work with, especially if it is already aged and smoked, in which case it becomes even lighter and stronger. The inside of a mask that has been hollowed out does not easily expand; it is easy to paint and apply with bronze; and it is durable (Pigeaud 1938: 14).

Pigeaud describes the method for mask-making in his time as follows. First, a piece of wood the size of a human face is hollowed out with a curved chisel to follow the curves of the mask from the inside. Second, an outline of the face is made, showing the lines of the mouth, nose, and eyes. Third, when the size is already clear, the wood is cut to match the correct size and shape for the figure that is to be portrayed. Fourth, when making a mask of Klana, or another figure with facial hair, the mask is shaped accordingly. Fifth, the brow and other features are finished, and given a form similar to that of a wayang purwa figure, then the headpiece and facial hair are carved, and the inside of the mask is hollowed out to the desired thickness. Holes are made for the mouth, nostrils, and eyes, the teeth are carved and positioned where the upper and lower lips meet. Sixth, the mask is smoothed and refined using bamboo wuluh and rempelas leaf to create a smooth surface, then the mask is painted and decorated with gold leaf. Seventh, when all this the work is finished, masks that require a moustache are fitted with black goat hair. Eighth, the mask is now considered complete and ready to be used in a performance (Pigeaud 1938, 14).

Studios or communities that support the Malang mask culture

Born in 1972 Handoyo (aged 48) owns and runs the Topeng Asmorobangun Studio in the hamlet of Kedungmonggo, in Pakisaji, Malang. The son of Taslan (the previous owner of the studio), he was encouraged by his parents to learn how to dance and to make masks. He began learning to dance, play gamelan, and make masks from his fourth year at elementary school. The topeng patih dance is the dance on which various other topeng dances are based. This dance is used as the opening dance in a performance of Malang mask dance.

Apart from learning to dance and play gamelan, Handoyo also learnt how to make masks. As the grandson of Karimun, an important mask artist from South Malang, he began making masks in 1978 when he was in his first year of middle school. In the beginning, he learnt how to make the mask of Panji. His method for learning was to copy other masks that already existed. He explains that a person who wants to learn the art of mask making should start with uncomplicated types of masks, and the mask of Panji (Panji Asmarabangun) is one of the masks to which he refers. The reason for choosing this mask is that it has a lower level of difficulty than sabrang (giant) masks. The shape of the face, the carvings, and other ornamental aspects are relatively easy to create. This type of mask also does not have complex additional features such as a moustache, the shape of its eyes is simple, and its carving is not too complicated.

There is no definite time frame for a person to achieve the level of a skilled artist. A learner's skills are usually assessed to determine when he is ready to learn other types of mask, especially sabrang masks. If a teacher declares that the mask made by a person learning the art is "already suitable" or "already good", he will then move on to begin learning to make patih masks. When his skills in this 
category are deemed by the teacher to be good enough, he then turns his attention to sabrang masks. This final category of mask is considered to be the most difficult. The difficulty in making a sabrang mask can be measured in quantitative terms. In order to produce a single sabrang mask, it takes as much time as is needed to make two or three Panji masks. If one or two Panji masks can be completed in a day, a single sabrang mask needs two to three days to complete. Handoyo, who employs five craftsmen skilled in the art of mask making, says that he needed ten years to reach his current level of expertise in the art of Malang mask making.

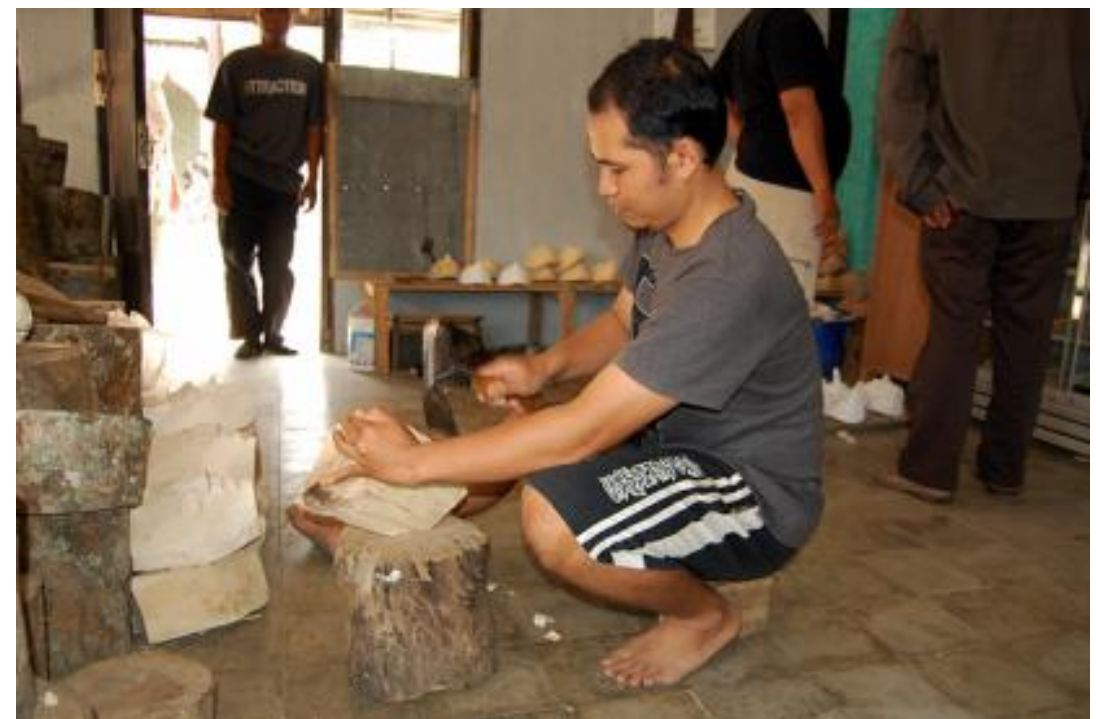

Fig. 9 Handoyo, a mask maker in Topeng Asmorobangun Studio, in the hamlet of Kedungmonggo, in Pakisaji, Malang. Source: Photo by Guntur and Nurohim.

The system through which Handoyo inherited the skills of mask making is the same as that experienced by Budi Utomo (aged 48). The owner of Topeng Setyotomo Studio in the hamlet of Glagahdowo, in the village of Pulungdowo, in the Tumpang sub-district of Malang, Budi Utomo learned to make masks together with his older brother and a group of friends. He is the only one out the group who has continued with the profession of mask making up to the present time. As a child, Budi Utomo learned the art of mask making from a number of local experts, including Rasimun, Gimun, Rahim, Jakimin, and Suep. He first began to learn at the age of 13, in his free time when he was not helping his parents in the rice fields. His learning process began with painting (mbilas malih) masks. The materials and tools for making the masks were provided by his teachers. 


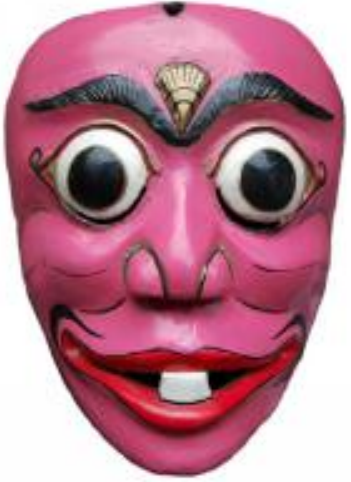

Prasonto Mask

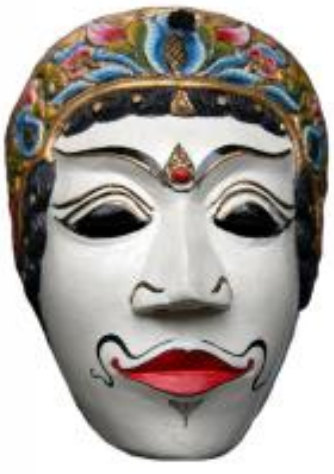

Raden Gunungsari Mask

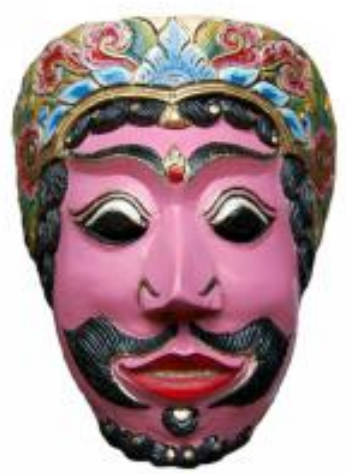

Patih Ngaronggo Kusumo Mask

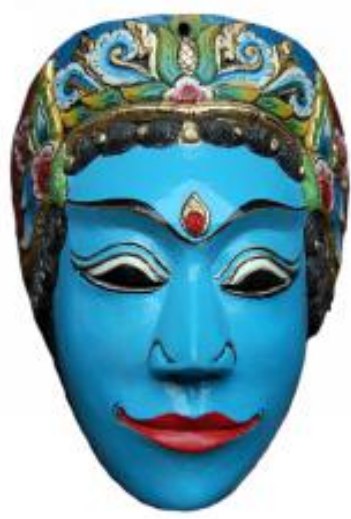

Panji Pambelah Mask

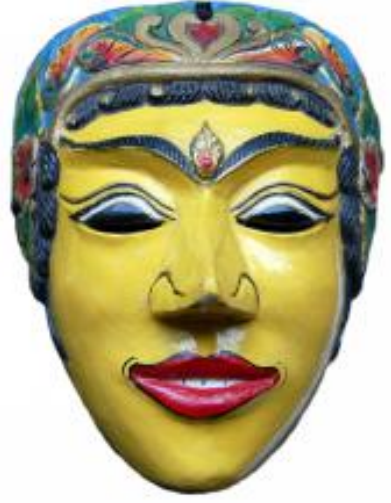

Panji Banyaksasi Mask

Fig. 10 Masks by Budi Utomo. Source: Photos by Guntur and Nurohim.

Although he learned the art of mask making at an early age, Budi Utomo did not pursue it as a profession until 2000 when he established his own mask dance studio. Since that time, he has made a complete set of masks for performance, consisting of 50 different types. However, due to the high demand for his work, he has still not realized his aspiration of owning a complete set of masks for his own studio.

In the experience of Budi Utomo, the stages in the process of creating a mask begin with drying the wood. The wood most commonly used is nyampu wood, a type of wood from the klecara kuning flower, which is considered to have the best quality and is not prone to disease. He once made a mask using mentaos wood but apart from that one time, he has always used nyampu because it is inexpensive, good quality, light, and does not easily crack.

During the drying process, the wood must be kept out of direct sunlight and simply left to air in an open space until it is completely dry. The dried wood is then cut according to the size of the mask to be made, which is usually around $25 \mathrm{~cm}$. The section of wood is divided into two, and each piece is cut into a rough triangular shape. The fingers are used for measuring. The beard is measured three fingers from the bottom, the 'live section' is four fingers in width, and the uppermost section is also four fingers. 
First, a broad outline is made for the nose, eyebrows, eyes, and lips. Then the forehead, hair, cheeks, and beard are measured. At this stage, the mask is halfway to being complete. More detail is then given to the eye sockets, nostrils, and hair. When the hair is finished, a decorative motif is made on the forehead (for the refined figures) and a beard (for the sabrang figures). The mask is then smoothed with sandpaper, given an undercoating, and painted. Budi Utomo says that in a month he can make ten masks.

Another mask maker, Suparjo (aged 50), learned the art of mask making as a teenager and this was an important milestone in determining his profession as a mask craftsman. The Director of Kesenian Topeng Jabung, who lives in the hamlet of Genthong, in the village of Argosari, in the sub-district of Jabung, Malang, Suparjo began learning to dance at the age of 9 and to make masks at the age of 12. It is common practice for mask craftsmen to learn the art from their parents. This was also the case with Suparjo, who learned how to make masks from his late father, Kusen. Suparjo learned together with his friends, but he is the only one amongst them who continues to practice the art of mask making today. He mentions one other friend, Misdi, who he says occasionally still make masks.

Originally, Suparjo learned to make Banyaksasi and Gunungsari masks. He learned to make these masks by coincidence. Somewhat different to Suroso, he says that there are not set standards or methods for a beginner learning the art of mask making. However, he is aware that making sabrang masks is more complicated than making Panji masks. The mask of Klana, for example, with its ornate headpiece, is not easy to create without a high level of skill. This kind of mask is more complex than the Panji mask or gunungsari mask. Throughout his career, Suparjo has made almost every different kind of mask but because of the high demand for his work, he still does not have his own set of masks.

According to Suparjo, all types of wood with smooth fibers can be used for making masks. However, he most often uses sengon wood or pine wood. These two types of wood are commonly found in the gardens of local inhabitants. Suparjo explains that mentaos wood, known for its high quality, is now extremely rare. Another kind of wood that can be used for mask making is dadapcangkring wood. 


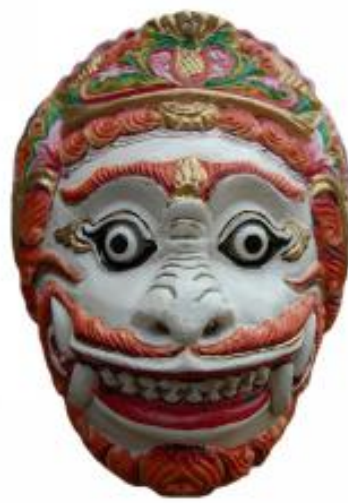

Topeng Bedes Mask

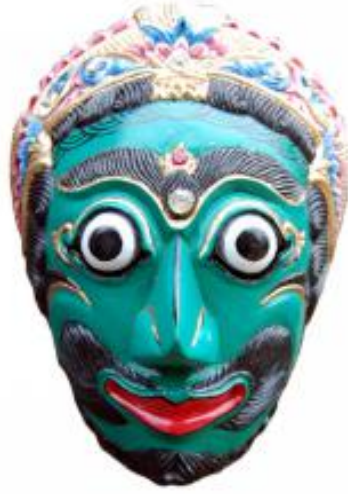

Patih Musing Jiwo Mask

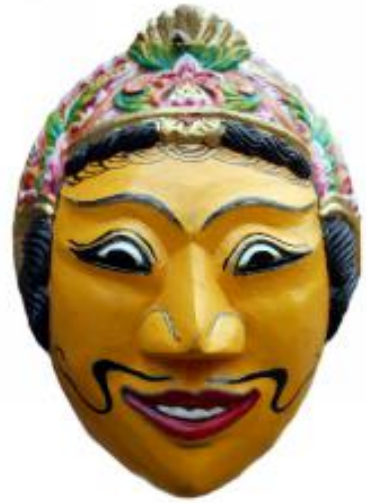

Panji Amerdadu Mask

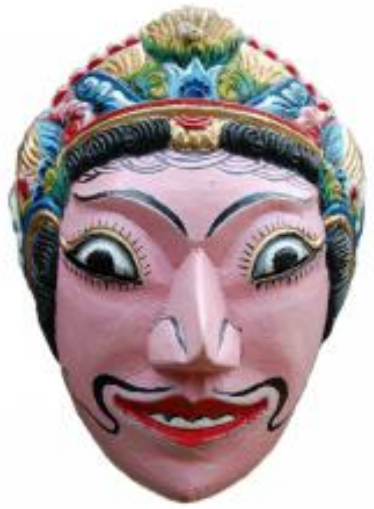

Panji Walang Semirang Mask

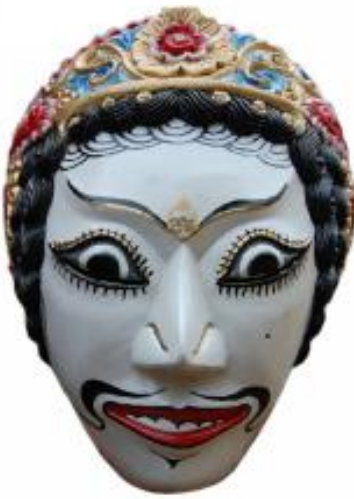

Raden Gunungsari Mask

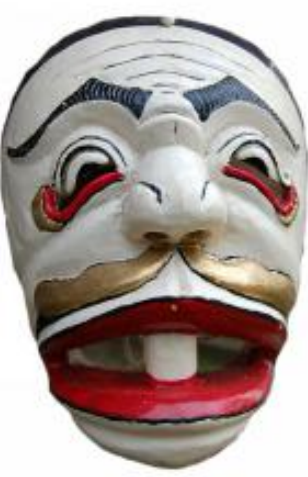

Jarodeh Mask

Fig. 11 Topeng Karya Suparjo. Source: Photo by Guntur and Nurohim.

In the process of mask making, Suparjo usually performs a ritual at the time when a tree is chopped down. As a part of this ritual, he fasts for seven days and stays awake for two whole days before beginning to make the mask. The goal of this is to prevent any misfortune or danger.

\section{Conclusion}

The dissemination of Indian culture in Indonesia has been recognized through the use of the mask in ancestral worship ritual and performance art. Sacred masks with a background of narration are compacted in the Panji story. The belief that spiritual beings are found in objects is embedded and preserved in the Panji tradition and demonstrated in many traditional performing arts such as kethoprak, barongan, and wayang. The threshold of the mask as a sacred object, carried over into a religious state of culture, has been passed on into the current era of artistry. The visual character of the mask is identified as a connection between the human and the supernatural, as spiritual imagology.

In general, Malang mask art has a unique tradition of creation, in terms of its form, lines, and carving, as well as in the concept of its coloring. The relationship between these artistic elements creates the personification of different figures with various categories of character. The categorization of Malang masks can be identified through the differences in color, as well as the different expressions used for each category of character. This expression is not only seen in the 
shape of the face but also in the choice of color used for the characterization of different figures. The system of colorization is symbolic and is also an artistic way of expressing character. The strength of the color red can express numerous different characteristics, and is used for figures who are arrogant, evil, and also courageous - which in fact sometimes have opposing roles. The color white is used to 'emphasize' a figure that is pure, refined, and noble. Black, meanwhile, which in the modern color system is the binary partner of the color white, is used to portray mask figures that are wise, discerning, and unwavering in both battle and service.

The shapes of the eyes, nose, and mouth are elements of expression in the actualization of a character. Emphasis and prominence of certain forms make it easy to recognize different characters through the stereotype of the facial expressions. The emphasis on the different facial elements varies from one figure to another, as does the difference in the shape of the face, with an oval shape and a pointed chin for refined and female figures, and a flatter, squarer chin for strong, masculine figures. The different eye shapes include blalakan, thelengan, and pananggalan. In terms of creation, each mask sculptor has his own unique style, which can be seen in the carved lines made with the special carving knife used. However, the differences between one craftsman and another do not detract from the general character of the Malang masks. The carved lines strengthen the character of the masks.

The function of the masks is to express the different characters of the figures portrayed in a dance performance. The existence of Malang masks is still closely connected with the art of wayang topeng and tari topeng, which are performed by community groups and government institutions such as art schools in East Java. In addition to functioning as a performance medium, Malang masks are also decorative objects.

In former times, mentaos wood was the most common type of wood used to make masks. Other kinds of light wood used in mask making include kweni, pelem, and kemiri wood. The material most frequently used for making masks in the Malang area in the past was dense, fibrous wood that did not easily break. Nowadays, in addition to mentaos wood, the types of wood used for mask making include kembang kenanga, pule, waru and cangkring wood. The tradition for mask making formerly centered on the passing down of skills from parents to children. This was also the case with the profession of mask making, and this factor affected the quality of the masks produced. Another common practice is for owners of art studios to be skilled as both mask performers and also mask craftsmen. Mask dancers are often in charge of studios or communities and also learn the art of mask making so that they are able to become skilled craftsmen. Some mask makers still perform rituals before beginning the mask making process in order to ward off danger or misfortune.

The practice of visualization in the facial expression of the masks functions to support the characterization of the different figures in a performance, with emphasis on personification. The visual expression of the masks portrays the characteristics of the different figures in the Panji story, a pre-Islamic legend which has become a folk tale (with Hindu Javanese narration) that has in fact 'already' experienced the dynamics of change and become a form of traditional Javanese art. Traditionality in the mask has taken place through a process of inheritance in which the art is passed down from one generation to the next. In terms of the materials used, the tradition is to use materials that are readily available in the local community, while techniques also continue to use traditional methods. 
The features of Malang masks appear rigid and the masks have thicker dimensions than masks from other areas. The shape of Malang masks presents a personification of human character and personality, especially in the three main features - the eyes, nose, and mouth. The different ways in which these three features are personified determines the characterization of the different categories of figures, such as gods, holy men, kings, governors, strong masculine figures, refined figures, female figures, and servants (Murgiyanto 1979/1980: 96). This categorization helps in the characterization of the shape of the face.

The manifestation of the mask would appear to conform to the character of the people in the place where the mask grew and developed. The different shapes and features of the masks display the creativity and individual style of each Malang mask artist, based on the acceptance of cultural conventions and combined with the creativity to develop according to the story presented in a wayang topeng performance. Malang masks, in all their shapes and forms, are strong and basic, with an impression of rigidity, roughness, and austerity, in accordance with the character of the supporting community. The style of the masks today refers to previous forms which are used as the master for modelling other masks. Developments in the shape of the masks are an indication of the creativity of artists, all of whom have their own unique style, without altering the character of the mask figures they create, since they adhere to existing conventions in their work. There are no striking differences in the techniques used for mask making. The diversity of mask form does not affect the characteristics of each mask figure, because each figure already has its own established visual form and role in the narration.

\section{References}

Andalas, EF (2016) Sastra Lisan Lakon Lahire Panji Pada Pertunjukan Wayang Topeng Malang Padepokan Mangun Dharma [Oral Literature of the Story of Panji’s Birth in Wayang Topeng Malang Performance at Padepokan Mangun Dharma]. MA thesis, Universitas Airlangga Surabaya.

Bell, D (2010) Mask Makers and Their Craft: an illustrated worldwide study. Jefferson, NC: McFarland.

Brandon, JR (1967) Theatre in Southeast Asia. Cambridge, MA: Harvard University Press.

Emigh, J (1996) Masked Performance: The Play of Self and Other in Ritual and Theatre. Philadelphia: University of Pennsylvania Press.

Forshee, J (2006) Culture and Customs of Indonesia. London: Greenwood Press.

Goodman, N (1978) Ways of Worldmaking. Indianapolis: Hackett Publishing Company.

Hidayat, R (2004) Wayang Topeng Malang di Dusun Kedungmonggo, Kajian Strukturalisme Simbolik Pertunjukan Tradisional di Malang [Wayang Topeng Malang in the Hamlet of Kedungmonggo, a Study of Symbolic Structuralism of Traditional Performance in Malang]. Master's Thesis, STSI Surakarta, Surakarta.

Hughes-Freeland, F (2008) Becoming a Puppet': Javanese Dance as Spiritual Art. The Journal of Religion and Theatre, 7(1): 35-54.

Kieven, L (2013) Following the Cap-Figure in Majapahit Temple Reliefs. Leiden: Koninklijke Brill NV.

Kieven, L (2014) Simbolisme Cerita Panji dalam Relief-Relief di Candi Zaman Majapahit dan Nilainya Pada Masa Kini [Symbolism of the Panji Story on Temple Reliefs from the 
Majapahit Era and their Values in the Present Day], paper presented at Seminar Naskah Panji [Seminar of Panji Manuscripts], October 28-29, Jakarta.

Kieven, L (2017) Getting Closer to the Primordial Panji? Panji Stories Carved in Stone at Ancient Javanese Majapahit Temples - and their Impact as Cultural Heritage Today. SPAFA Journal, 1(1): 1-24.

Kieven, L (2020) Panji and Sekartaji on the Move. Wacana, 21(1): 69-102.

Metcalf, B (1997) Craft and Art, Culture and Biology. In: P Dormer (ed.) The Culture of Craft. Manchester and New York: Manchester University Press, 67-82.

Meyer, LB (1987) Toward a Theory of Style. In: B Lang (ed.) The Concept of Style. Ithaca, NY: Cornell University Press.

Moore, AC (1977) Iconography of Religions, An Introduction. Philadelphia: Fortress Press.

Murgiyanto, S and Munardi, AM (1979/1980) Topeng Malang. Jakarta: Departemen Pendidikan dan Kebudayaan, Direktorat Jendral Kebudayaan.

Napier, DA (1986) Mask, Transformation, and Paradox. London: University of California Press. Onghokham (1972) The Wayang Topèng World of Malang. Indonesia, 14: 111-124.

Pigeaud, T (1938) Javaanese Volksvertoningen, Bijdragen tot de beschrijving van land en volk. [Javanese Folk Displays, Contributions to the Description of Land and People]. Batavia: Volkslectuur.

Pigeaud, TGT (1962) Java in the 14th Century. A Study in Cultural History. Leiden: Verhandelingen van het Koninklijk Instituut voor Taal-, Land- en Volkenkunde.

Poerbatjaraka (1931) Smaradahana. Bandoeng: Bibliotheca Javanica, A.C. Nix.

Proschan, F (1983) The Semiotic Study of Puppets, Masks, and Performing Objects. Semiotica, 47(1): 3-46.

Ras, J (1973) The Panji Romance and W.H. Rassers analysis of its theme. Bijdragen tot de Taal-, Land- en Volkenkunde, 129(4): 411-456.

Ras, J (2014) Masyarakat dan Kesusastraan di Jawa [Society and Literature in Java]. Trans. Achadiati Ikram. Jakarta: Yayasan Pustaka Obor.

Ricklefs, MC (2013) Mengislamkan Jawa. Sejarah Islamisasi di Jawa dan Penentangnya dari 1930 sampai Sekarang [Islamizing Java. The History and Resistance of Islamization in Java from 1930 to the Present Day]. Jakarta: PT. Serambi Ilmu Semesta.

Schapiro, M (1953) Style. In: AL Kroeber (ed.) Anthropology Today, an Encyclopedic Inventory. Chicago: The University of Chicago Press, 287-312.

Soedarsono, RM (1997) Wayang Wong: Drama Tari Ritual Kenegaraan di Keraton Yogyakarta [Wayang Wong: State Ritual Dance Drama in the Yogyakarta Palace]. Yogyakarta: Gadjah Mada Press.

Suanda, E (1985) Cirebonese Topeng and Wayang of the Present Day. Asian Music, 16(2): 84-120.

Suardana, IW (2015) Struktur Rupa Topeng Bali Klasik [Visual Structure of Classical Balinese Masks]. Imaji, 4(1): 74-86.

Supriyanto, H and M. Soleh Adi Pramono (1997) Drama Tari Wayang Topeng Malang [Wayang Topeng Malang Dance Drama]. Tumpang-Malang: Padepokan Seni Mangun Dharma.

Tonkin, E (1992) Mask. In: R Bauman (ed.) Folklore, Cultural Performances, and Popular Entertainments. New York: Oxford University Press, 225-233.

Winstedt, RO (1969) A History of Classical Malay Literature. Kuala Lumpur: Oxford University Press. 